\title{
Initiation of symbiosis between the soft coral Heteroxenia fuscescens and its zooxanthellae
}

\author{
Zohar Pasternak $^{1,2, *}$, Ami Bachar ${ }^{1}$, Avigdor Abelson'², Yair Achituv ${ }^{1}$ \\ ${ }^{1}$ Faculty of Life Sciences, Bar-Ilan University, Ramat-Gan 52900, Israel \\ ${ }^{2}$ Institute for Nature Conservation Research, Tel-Aviv University, Tel-Aviv 69978, Israel
}

\begin{abstract}
Symbiotic dinoflagellates of the genus Symbiodinium, commonly referred to as zooxanthellae, inhabit a large portion of the world's corals and are essential for the existence and well being of tropical reef ecosystems. The initiation of this symbiosis was studied using the Red-Sea soft coral Heteroxenia fuscescens. Results show that the motile algal cells are attracted to chemical substances emanating from the mouths of juvenile (zooxanthellae-free) polyps but not of adult (zooxanthellaebearing) ones. The oral acquisition of symbionts is immediate; within $15 \mathrm{~min}$ of encountering the polyp, $15.6 \pm 5.2$ cells gain access into it. Once initial acquisition is concluded, the net number of algae within the polyp does not change significantly over the next $3 \mathrm{~h}$, while algae continue to penetrate through and be expelled from the polyp mouth.
\end{abstract}

KEY WORDS: Algal acquisition $\cdot$ Symbiosis $\cdot$ Coral reef $\cdot$ Zooxanthellae $\cdot$ Chemotaxis

\section{INTRODUCTION}

Symbiotic dinoflagellates of the genus Symbiodinium, commonly referred to as zooxanthellae, inhabit a wide range of hosts, including members of the Protozoa, Porifera, Cnidaria, Platyhelminthes and Mollusca (Trench 1993). The most widespread, and perhaps the most important, symbioses are with Anthozoan cnidarians, namely hard and soft corals: the photosynthetic zooxanthellae provide the corals with energy-rich food (Muscatine 1990), which is ultimately essential for the existence and well being of tropical reef ecosystems (Levinton 1995). Acquisition of dinoflagellates in marine cnidarians is done via 2 main avenues: (1) vertically (a 'closed system'), in which new corals are provided with algal cells by maternal inheritance via the eggs or (in the case of brooders) the larvae, or (2) horizontally (an 'open system'), in which they acquire algal cells from the ambient environment (Trench 1987, Douglas 1994). Open systems occur in $~ 85 \%$ of cnidarian species hosting zooxanthellae, including hard and soft corals (Kinzie 1974, Harrison \& Wallace 1990, Richmond 1997), their advantage presumably being the ability to choose the algal partners which are best adapted to conditions in the host's eventual habitat (Buddemeier \& Fautin 1993). Algal acquisition from the environment may take place at the embryonic stage (the scyphozoan Linuche unguiculata; Montgomery \& Kremer 1995), the planula larval stage (e.g. the scleractinian coral Fungia scutaria; Krupp 1983) or the metamorphosed polyp stage (e.g. the soft coral Heteroxenia fuscescens; Benayahu et al. 1989).

Motile zooxanthellae may swim toward and congregate near the mouths of sedentary host polyps of several cnidarian species, where they are consequently engulfed and presumably phagocytosed into endodermal cells (Kinzie 1974, Fitt 1984). This phenomenon was suggested to also occur in the Red Sea soft coral Heteroxenia fuscescens (Octocorallia: Alcyonacea). From a very early stage of the juvenile polyp of $H$. fuscescens, motile algal cells tended to swim towards its open mouth, aggregating around and finally entering the oral disc. Once inside the gastrovascular cavity, algal cells were endocytoced by the host gastrodermis and endosymbiosis ensued (Yacobovitch 2001). There are, however, several important questions that remained unanswered: what is the mechanism attracting the algal cells to the mouth of the polyp? What is the 
polyp's role in accepting or rejecting the entrance of symbionts? And finally, is the acquisition of symbionts continuous or episodic, i.e. does it cease after an initial acquisition event? Our study aimed at finding the answers to these questions, thus further elucidating the initial processes involved in the establishment of symbiosis between $H$. fuscescens and its zooxanthellae.

\section{MATERIALS AND METHODS}

Biological material. Mature dimorphic colonies of Heteroxenia fuscescens were randomly sampled from the Red Sea coral reef (3 to $8 \mathrm{~m}$ deep) near the Inter University Institute of Eilat, Israel, in June 2002. Planulae were collected as described in Ben-David-Zaslow \& Benayahu (1996), and were kept in $0.2 \mu \mathrm{m}$-filtered seawater (FSW) to avoid bacterial contamination. The planulae and their respective parental colonies were transported to Bar-Ilan University, where they were provided a 12L:12D light cycle and a constant temperature of $25^{\circ} \mathrm{C}$, corresponding to the ambient Red Sea water temperature at the time. Planulae were placed in Petri dishes, 4 to 10 per dish, which were filled with $0.45 \mu \mathrm{m}$ FSW. Water was replaced every other day. After $14 \mathrm{~d}$ the planulae metamorphosed into primary polyps. In order to isolate zooxanthellae algal cells, 10 polyps from an adult parental $H$. fuscescens colony were homogenized in $0.5 \mathrm{ml}$ of $0.2 \mu \mathrm{m}$ FSW. The homogenate was then transferred to $1.5 \mathrm{ml}$ sterile microfuge tubes which were centrifuged for $15 \mathrm{~min}$ at $300 \times g(1500 \mathrm{rpm})$. The supernatant was discarded and the algal pellet was re-suspended with FSW and centrifuged for a further $5 \mathrm{~min}$ at $300 \times \mathrm{g}$. This last procedure was repeated 3 times in order to obtain clean algal preparations, which were then transferred to $100 \mathrm{ml}$ sterile tubes containing $75 \mathrm{ml}$ of $\mathrm{F} / 2$ nutrient solution (vitamin B12 $0.05 \mathrm{mg} \mathrm{l}^{-1}$, biotin $0.01 \mathrm{mg} \mathrm{l}^{-1}$, thiamine $\mathrm{HCl} 0.17 \mathrm{mg} \mathrm{l}^{-1}$; Guillard 1975). After $3 \mathrm{~d}$ under a 12L:12D light cycle and at a constant temperature of $25^{\circ} \mathrm{C}$, the algal cells became motile and were introduced into the experiments.

Chemical attraction experiment. Adult (zooxanthellate) polyps and juvenile (azooxanthellate) polyps were separately homogenized. The pellets were discarded and the supernatants were repeat-centrifuged until the solutions became clear to the eye and contained no algae when examined under a microscope. Three drops were then loaded onto Nitrocellulose (NC) paper: (1) adult-polyp solution, (2) juvenile-polyp solution, and (3) sea-water solution. The drops were placed $1 \mathrm{~cm}$ from each other to form a triangle, and the NC paper was immersed in a petri dish filled with FSW and motile algal cells. Algal motion and settlement was filmed using an epi-fluorescent stereoscope attached to a video camera. The excitation and emission wavelength filters were set to detect chlorophyll. This experiment was repeated 16 times.

Algal acquisition experiment. Algal cells were immersed in sterilized, $0.2 \mu \mathrm{m}$ FSW containing radioactive carbon $\left({ }^{14} \mathrm{C}\right)$. After $48 \mathrm{~h}$, progressive-dilution readings showed that each cell contained $5.35 \mathrm{cpm}$ of radioactivity. To 14 petri dishes, each containing 4 juvenile (azooxanthellate) polyps, we added $1 \mathrm{ml}$ of radioactive motile algae. In the first $2 \mathrm{~h}$, a petri dish was removed every $15 \mathrm{~min}$ and its 4 polyps washed with sterilized FSW to clean their outer surface of any algal cells which may have attached to them. Then, each polyp was separately immersed in OptiFluor scintillation oil and its radioactivity level was determined. In the following $75 \mathrm{~min}$, this procedure was repeated every $25 \mathrm{~min}$.

\section{RESULTS}

In the chemical attraction experiments (Fig. $1 ; \mathrm{N}=16$ repeats) almost all algae $(97 \pm 2 \%)$ were attracted to the solution containing exudates of juvenile (zooxanthellae-free) polyps, while a small fraction $(3 \pm 1 \%)$ were attracted to the solution containing exudates of adult (zooxanthellae-bearing) polyps and none $(0 \pm 0 \%)$ to sea-water control. All symbionts swarmed towards the juvenile chemicals and settled on them within 15 min of the algae being introduced into the experimental containers. In the algal acquisition

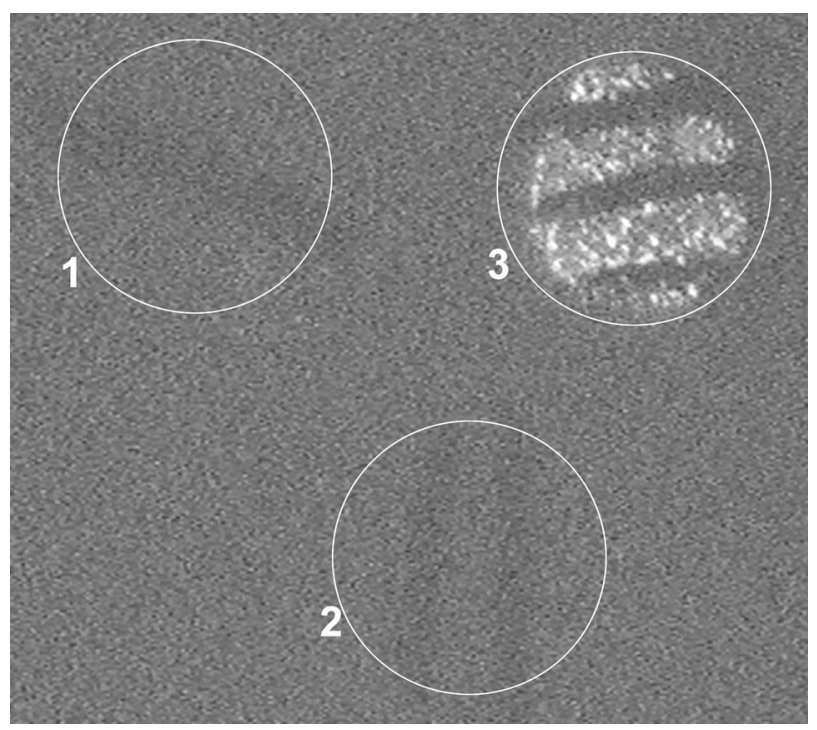

Fig. 1. Symbiodinium sp. Attraction of algal cells to drops of exudate-solution of (1) adult polyps, (2) sea water control and (3) juvenile polyps. The chlorophyll-containing algae are bright against the background 


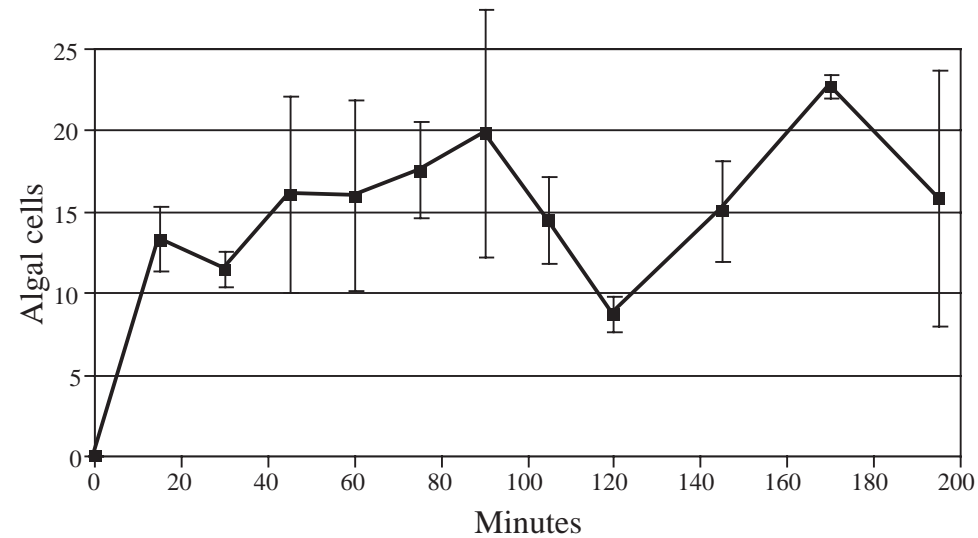

Fig. 2. Symbiodinium sp. Numbers of algal cells (mean \pm SD) inside coral polyps as a function of time since algae were introduced into the polyp's environment.

experiment (Fig. 2), within 15 min of the algae encountering the juvenile polyps, the polyps already contained algae in a quantity that did not change significantly over the next $3 \mathrm{~h}$ (Kruskal-Wallis test, $H=16.11$, $\mathrm{p}=0.0966)$. When pooled over the entire time of the experiment, polyps contained $15.6 \pm 5.2($ mean $\pm \mathrm{SD})$ cells.

\section{DISCUSSION}

We conclude that motile algal cells are attracted to chemical substances emanating from the mouths of juvenile (zooxanthellae-free) Heteroxenia fuscescens polyps but not of adult (zooxanthellae-bearing) ones. The oral acquisition of symbionts is immediate, with the

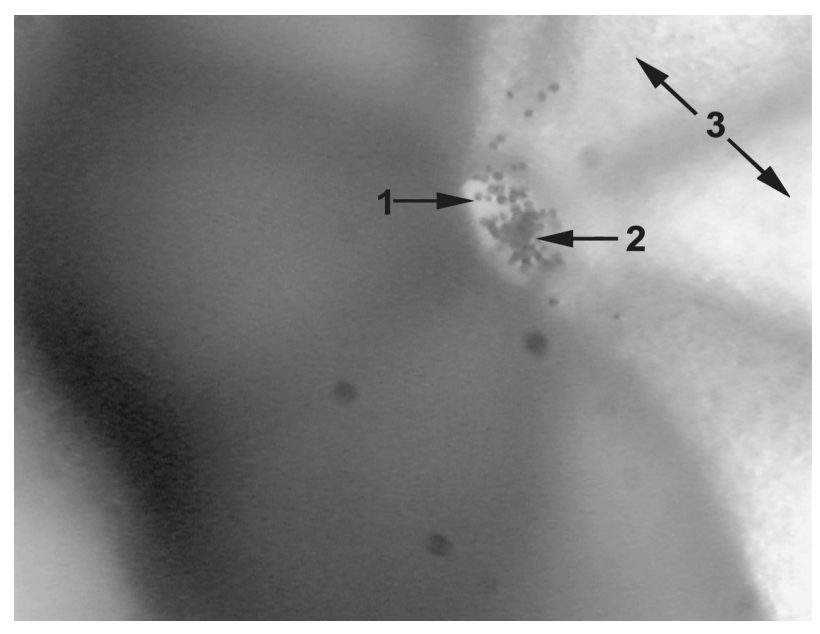

Fig. 3. Symbiodinium sp. and Heteroxenia fuscescens. Algal ejection event. (1) Polyp mouth, (2) 'ball of twine' containing caught algal cells, being ejected through mouth of polyp, (3) polyp tentacles initial acquisition of $15.6 \pm 5.2$ algal cells taking place within the first $15 \mathrm{~min}$ of encounter. From our results it cannot be ascertained whether algal acquisition is episodic or continuous, and both hypotheses remain possible: first, that after the initial acquisition event is concluded, algal cells continue to enter the polyp but are not endocytosed by it and are periodically expelled; and second, that continuous algal uptake and endocytosis are counteracted by continuous expulsion at an equal rate. Both hypotheses may find support in visual observations of 'balls of twine', in which many algal cells are entangled, periodically being ejected through the polyp's mouth (Fig. 3; see also movie of algae being ejected at www.int-res.com/journals/suppl/ pasternak_video.mpg). Therefore, more research is required in order to elucidate this matter.

Acknowledgements. The authors would like to thank S. Glazer and S. Klarfeld from Bar-Ilan University and Prof. Y. Benayahu, A. Maoz and E. Sapir from Tel-Aviv University. This work is part of a dissertation of Z.P. towards his PhD degree.

\section{LITERATURE CITED}

Benayahu Y, Achituv Y, Berener T (1989) Metamorphosis of an octocoral polyp and its infection by algal symbiont. Symbiosis 7:159-169

Ben-David-Zaslow R, Benayahu Y (1996) Longevity, competence and energetic content of the soft coral Heteroxenia fuscescens. J Exp Mar Biol Ecol 206:55-68

Buddemeier RW, Fautin DG (1993) Coral bleaching as an adaptive mechanism: a testable hypothesis. BioScience 43 $320-326$

Douglas AE (1994) Symbiotic interactions. Oxford University Press, Oxford

Fitt WK (1984) The role of chemosensory behavior of Symbiodinium microadriaticum, intermediate hosts, and host behavior in the infection of coelenterates and molluscs with zooxanthellae. Mar Biol 81:9-17

Guillard RRL (1975) Culture of phytoplankton for feeding marine invertebrates. In: Smith WL, Chanley MH (eds) Culture of marine invertebrate animals. Plenum Press, New York, p 26-60

Harrison PL, Wallace CC (1990) Reproduction, dispersal and recruitment of scleractinian corals. In: Dubinsky Z (ed) Ecosystems of the world, Vol 25. Coral reefs. Elsevier, Amsterdam, p 133-207

Kinzie RA (1974) Experimental infection of aposymbiotic gorgonian polyps with zooxanthellae. J Exp Mar Biol Ecol 15: $335-345$

Krupp DA (1983) Sexual reproduction and early development of the solitary coral Fungia scutaria (Anthozoa: Scleractinia). Coral Reefs 2:159-164

Levinton, JS (1995) Marine Biology: function, biodiversity, ecology. Oxford University Press, New York

Montgomery MK, Kremer PM (1995) Transmission of symbiotic dinoflagellates through the sexual cycle of the host scyphozoan Linuche unguiculata. Mar Biol 124:147-155

Muscatine L (1990) The role of symbiotic algae in carbon and energy flux in reef corals. In: Dubinsky Z (ed) Ecosystems of the world, Vol. 25. Coral reefs. Elsevier, Amsterdam, p 75-87 
Richmond RH (1997) Reproduction and recruitment in corals: Critical links in the persistence of reefs. In: Birkeland C (ed) Life and death of coral reefs. Chapman Hall, New York, p 75-87

Trench RK (1987) Dinoflagellates in non parasitic symbioses. In: Taylor FJR (ed) The biology of dinoflagellates. Black-

Editorial responsibility: Otto Kinne (Editor),

Oldendorf/Luhe, Germany well, Oxford, p 175-197

Trench RK (1993) Microalgal-invertebrate symbiosis: a review. Endocyt Cell Res 9:135-175

Yacobovitch T (2001) Acquisition of zooxanthellae by a sexually-produced aposymbiotic offspring of the soft coral Heteroxenia fuscescens. MSc thesis, Tel-Aviv University

Submitted: December 2, 2003; Accepted: June 8, 2004

Proofs received from author(s): September 15, 2004 